\title{
Od autorów
}

Monografia Trwała obecność mitu w literaturze i kulturze jest efektem działalności naukowej studencko-doktoranckiego Koła Naukowego Mitokrytyków Uniwersytetu Łódzkiego. Celem działalności Koła jest propagowanie i rozwijanie badań mitokrytycznych nad tekstem literackim oraz umożliwianie rozwoju naukowego młodych badaczy w zakresie tematyki rzadko podejmowanej w obrębie polskich badań literaturoznawczych. Przedmiot zainteresowania autorów i redaktorów tomu stanowi literatura odczytywana jako obszar palingenezy mitu. Zakres tematyczny monografii obejmuje takie zagadnienia, jak: teoretyczne ujęcia mitu w perspektywie antropologicznej, rewitalizacja mitu w kulturze współczesnej; przetworzenie paradygmatów czasu mitycznego i mitycznych modeli kosmicznych w tekstach kultury; hermeneutyka tekstów literackich, stanowiących artystyczną transpozycję archaicznych narracji mitycznych.

Inspiracją do powstania tomu była ogólnopolska studencko-doktorancka konferencja naukowa zorganizowana przez członków Koła Naukowego Mitokrytyków UŁ w Łodzi w dniach 27-28 marca 2015 roku. 